\title{
Four ectopia cordis cases surgically managed with different strategies
}

\author{
Farklı stratejiler ile cerrahi olarak tedavi edilen dört ektopia kordis olgusu

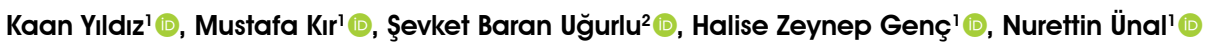 \\ 'Department of Pediatric Cardiology, Dokuz Eylül University Faculty of Medicine, Izmir, Turkey \\ ${ }^{2}$ Department of Cardiovascular Surgery, Dokuz Eylül University Faculty of Medicine, Izmir, Turkey
}

\begin{abstract}
Ectopia cordis is a rare congenital disorder in which the heart is partially or completely located outside the chest cavity. In this article, we present four cases of ectopia cordis accompanied by cardiac abnormalities with either thoracic and/or abdominal placed heart, managed with strategies ranging from follow-up without any intervention to complete surgical closure.
\end{abstract}

Keywords: Congenital heart disease, ectopia cordis, pentalogy of Cantrell, surgical treatment.

Ectopia cordis (EC) is a rare congenital disorder in which the heart is partially or completely outside the thoracic cavity. It approximately occurs at a rate of 5.5 to 7.9 per one million live births and constitutes $0.1 \%$ of all congenital heart diseases. ${ }^{[1]}$ It is frequently associated with cardiac anomalies such as ventricular septal defects (VSDs), atrial septal defects (ASDs), pulmonary stenosis (PS), right ventricular (RV) diverticulum, double outlet right ventricle (DORV), and tetralogy of Fallot. ${ }^{[2]}$ Non-cardiac disorders such as omphalocele, gastroschisis, scoliosis, cleft palate/lip, and central nervous system disorders can be also seen frequently with EC. ${ }^{[3]}$ The follow-up and treatment of this rare pathology vary depending on each individual patient and there is no consensus currently.

In this article, we report four cases of EC accompanied by cardiac abnormalities with either thoracic and/or abdominal placed heart and managed with different approaches.

\section{$\ddot{O} Z$}

Ektopia kordis kalbin kısmen veya tamamen göğüs boşluğu dışında bulunduğu nadir bir doğumsal bozukluktur. Bu makalede, herhangi bir girişim olmaksızın takipten tam cerrahi kapatmaya kadar çeşitlilik gösteren stratejiler ile tedavi edilen, kardiyak anomalilerin eşlik ettiği, torakal ve/veya abdominal yerleşimli dört ektopia kordis olgusu sunuldu.

Anahtar sözcükler: Doğumsal kalp hastalı̆̆ı, ektopia kordis, Cantrell pentalojisi, cerrahi tedavi.

\section{CASE REPORT}

Case 1- The first case was a girl, delivered by a cesarean section weighing $2,930 \mathrm{~g}$ at the $35^{\text {th }}$ gestational week. She had a predominantly abdominal EC and with the heart located outside the body below the sternum (Figure 1a). There was a large gap in the diaphragm, both ventricles protruding from the gap. Pericardium was absent. There was a large omphalocele below the ventricles covered with a thin membrane. A previous fetal echocardiography suggested an unbalanced atrioventricular septal defect in addition to EC. Post-natal echocardiography did not support this finding and showed a normal-size right and left ventricles. The left and right atrium were deformed and partially located in the mediastinum. There was a large ASD. Aorta and pulmonary artery were abnormal and elongated. The left ventricular outflow tract (LVOT) was narrow at the point of entry into the chest, showing a peak gradient of $65 \mathrm{mmHg}$. Additional physical findings were a short, webbed neck

Received: April 06, 2020 Accepted: September 30, 2020 Published online: January 13, 2021

Correspondence: Kaan Yıldız, MD. Dokuz Eylül Üniversitesi Tıp Fakültesi Çocuk Kardiyolojisi Kliniği, 35340 Balçova, Izmir, Türkiye. Tel: +90 232 - 4126178 e-mail: drkaanyildiz@gmail.com 

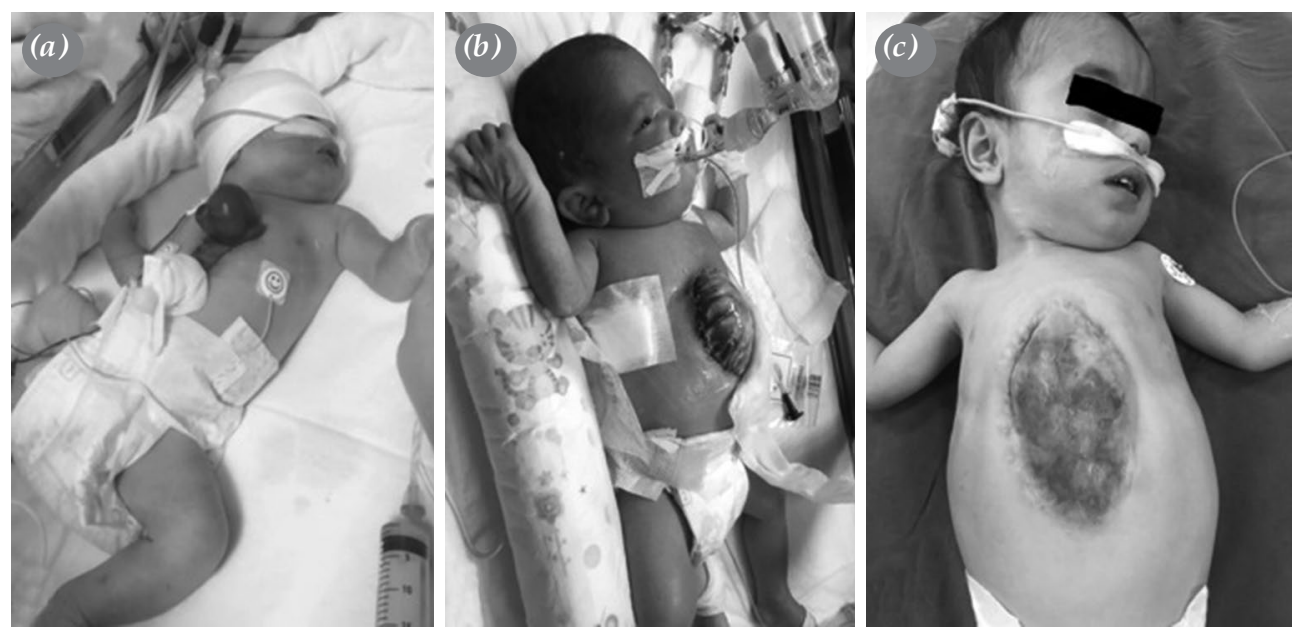

Figure 1. Serial photographs of Case 1 (a) Newborn period ectopia cordis. (b) Surgical closure with a porcine pericardial patch. (c) At the age of one year, epithelialized defect following detachment of the patch.

and a simian line with bilateral sandal gaps in the right hand.

The patient was operated on post-natal Day 6 . During the operation, the defect in the diaphragm was enlarged, the omphalocele was opened. The exposed ventricles were placed in the resulting single large orifice in the abdomen. The large defect was covered completely with a large porcine pericardial patch (Figure 1b). The patient was recovered from the operation and was successfully extubated and discharged to home after two months. During follow-up, the porcine pericardial patch was dislodged spontaneously eight months after the operation. The resulting defect was found to be completely covered with neo-epithelium (Figure 1c).
During follow-up, the patient showed a significant growth failure requiring frequent hospitalizations for cardiac and respiratory symptoms. Echocardiographic examinations revealed significant narrowing of the LVOT and pulmonary hypertension. A diagnostic angiography was performed at 19 months age which revealed a thin, narrow, and elongated LVOT (Figure 2a). Pressures were as follows: left ventricle 135/0-6 mmHg and aorta 75/44 (median: $57 \mathrm{mmHg}$ ). The systolic pulmonary artery pressure was $64 \mathrm{mmHg}$. Surgical treatment was abandoned due to anatomical considerations, and medical treatment with bosentan and sildenafil for pulmonary hypertension was started. Eventually, the pulmonary artery was dilated due to hypertension reaching twice the size of aorta (Figure 2b). Unfortunately, at the age of two years,
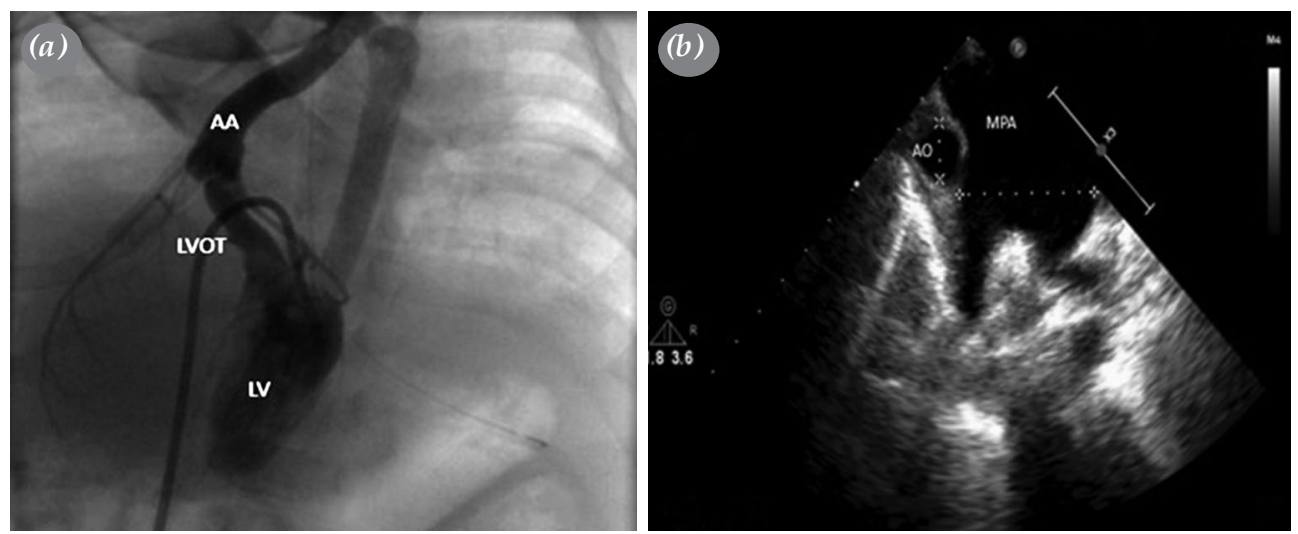

Figure 2. Imaging studies of Case 1. (a) Thin and elongated LVOT on angiography. (b) Short axis parasternal two-dimensional echocardiographic image showing aneurysmatic pulmonary artery. AA: Ascending aorta; LVOT: Left ventricular outflow tract; LV: Left ventricle; Ao: Aorta; MPA: Main pulmonary artery. 

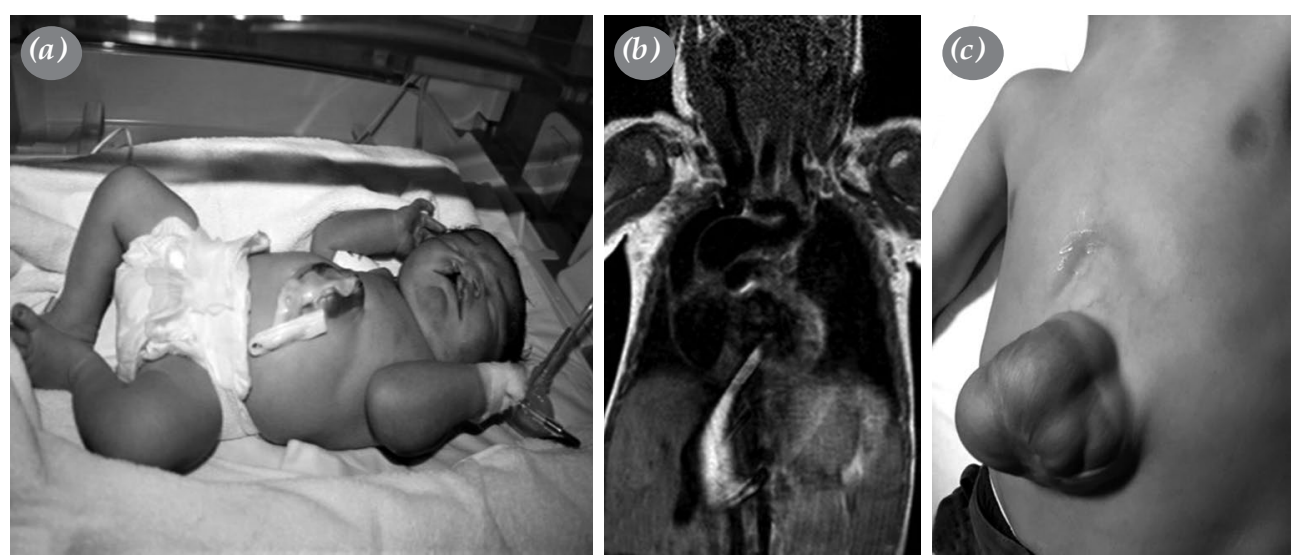

Figure 3. Images of Case 2. (a) Neonatal image with ectopia cordis. (b) Cardiac magnetic resonance imaging showing double outlet right ventricle. (c) The follow-up image at the age of six years.

while the patient was evaluated for delayed neurological development, a cranial and spinal magnetic resonance imaging (MRI) study under sedation resulted in cardiac arrest requiring resuscitation. The patient was lost three weeks after the episode due to sepsis and multiple organ failure. A written informed consent was obtained from each parent for all diagnostic and therapeutic procedures.

Case 2- After normal delivery of a 4,000-g, 39-week-old male infant, he was diagnosed with partial thoracoabdominal EC in addition to cleft palate/lip and Pentalogy of Cantrell. There was a ventral supraumbilical defect in which the heart was partially located (Figure 3a). Echocardiography revealed DORV with a large VSD, PS, and persistent superior vena cava. A cardiac MRI was performed for defining anatomical relationships more clearly (Figure 3b). A diagnostic angiography showed transposed DORV and subpulmonic significant PS. The RV had a large diverticulum placed toward the apex protruding from the defect. Cleft palate/lip repair was performed at 14 months of age. The patient underwent a left modified Blalock-Taussig (mBT) shunt operation at the age of four years for cyanosis. The patient is currently six years old, and the defect has decreased in size relative to the body with normal growth and development and is covered with epithelium (Figure 3c). A written informed consent was obtained from each parent for all diagnostic and therapeutic procedures.

Case 3- A 3,020-g male infant born at $37^{\text {th }}$ week of gestation by cesarean section was diagnosed with thoracoabdominal EC and omphalocele. Echocardiography revealed DORV, a wide inlet VSD, arterial malposition, primum ASD, PS, and patent ductus arteriosus (PDA). Omphalocele and diaphragmatic hernia were repaired at the age of two and a half months. At the age of two years, a diagnostic angiography confirmed the diagnosis. Pulmonary arteries were hypoplasic with a McGoon index of 1.3. Total correction was deemed unfeasible and the patient underwent a right $\mathrm{mBT}$ shunt. The right $\mathrm{mBT}$ shunt obstruction was seen at the age of six years, and a left-sided mBT shunt was performed. $\mathrm{He}$ is currently 12 years old with normal growth and

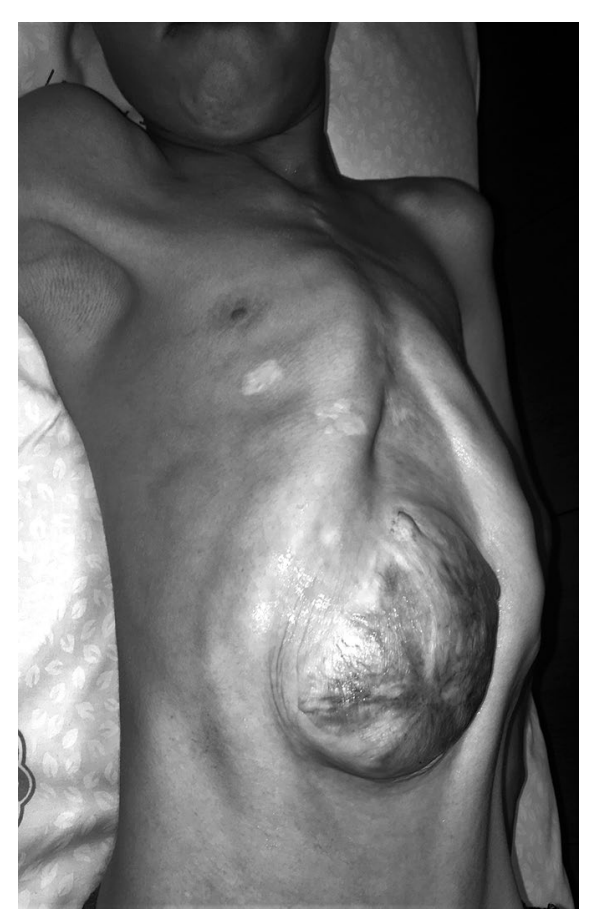

Figure 4. A follow-up image of Case 3 at the age of 12 years. 

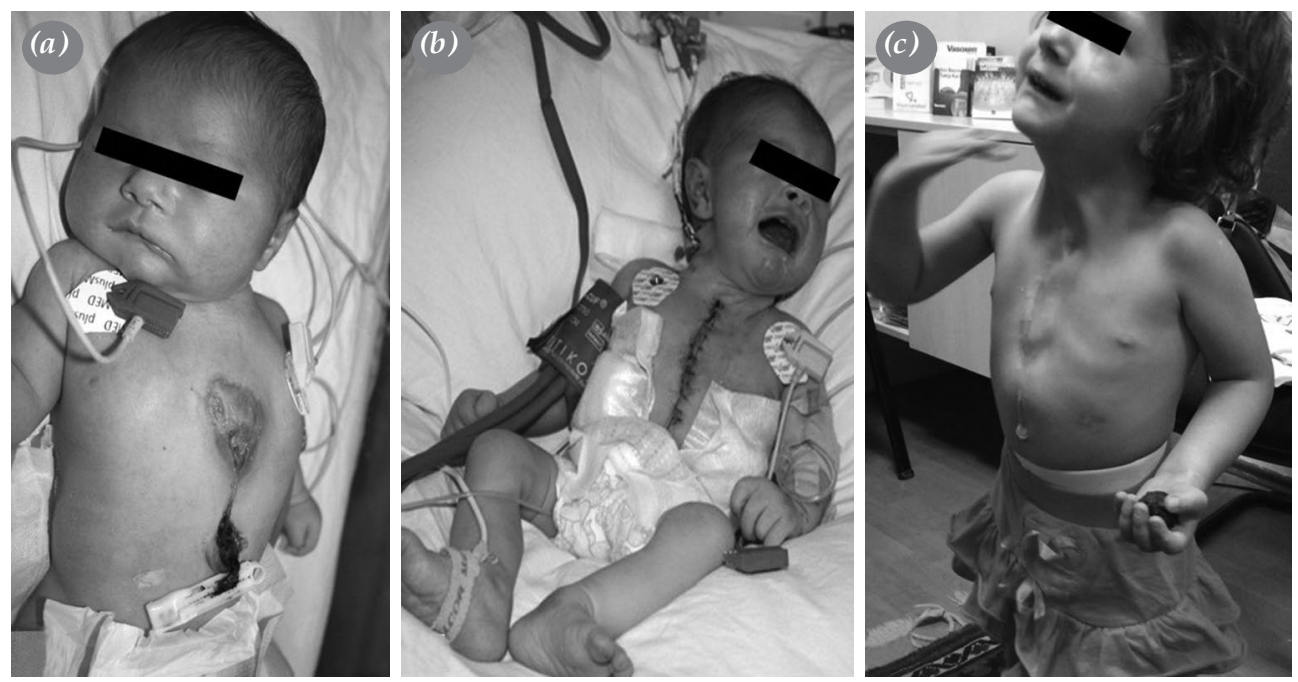

Figure 5. Serial photographs of Case 4. (a) Preoperative image showing anterior chest wall defect. (b) After closure of the defect. (c) A follow-up image at the age of five years.

development (Figure 4). A written informed consent was obtained from each parent for all diagnostic and therapeutic procedures.

Case 4- A seven-day old girl infant was referred from another province with the diagnosis of EC, ASD, and PDA. Initial examination revealed a term, healthy infant with a midsternal defect from which the heart was readily observable (Figure 5a). Pericardium partially covered the exposed heart. The patient was operated urgently upon arrival. At the operation, the sternum was found to be completely bifid. There was a persistent left superior vena cava and the PDA was ligated. Aorta, superior, and inferior vena cava were cannulated, and the 7-mm ASD was closed with primary suture under cardioplegic arrest. For closure of the thoracic defect, both sides of the sternum were mobilized by detaching the sternoclavicular joints. Pectoralis major muscles were also mobilized. These

Table 1. Demographic and clinical characteristics of cases

\begin{tabular}{|c|c|c|c|c|c|c|c|}
\hline Case & Sex & $\begin{array}{l}\text { Age at initial } \\
\text { treatment }\end{array}$ & $\begin{array}{l}\text { Age at last } \\
\text { follow-up }\end{array}$ & Ectopia cordis type & $\begin{array}{c}\text { Intracardiac } \\
\text { pathology }\end{array}$ & $\begin{array}{c}\text { Other } \\
\text { anomalies }\end{array}$ & Treatment \\
\hline 1 & Female & Neonate & 2 & $\begin{array}{l}\text { Predominantly } \\
\text { abdominal }\end{array}$ & $\begin{array}{c}\text { ASD, AS } \\
\text { (subvalvular), } \\
\text { LPSVC }\end{array}$ & Omphalocele & $\begin{array}{c}\text { Covered with } \\
\text { porcine } \\
\text { pericardial patch }\end{array}$ \\
\hline 2 & Male & 3 years & 6 & Thoracoabdominal & $\begin{array}{l}\text { DORV, VSD, } \\
\text { arterial } \\
\text { malposition, } \\
\text { PS, PDA ASD } \\
\text { (primum) }\end{array}$ & $\begin{array}{c}\text { Omphalocele, } \\
\text { diaphragmatic } \\
\text { hernia }\end{array}$ & $\begin{array}{l}\text { Omphalocele } \\
\text { and } \\
\text { diaphragmatic } \\
\text { hernia repair, } \\
\text { mBT shunt } \\
\text { (left and right) }\end{array}$ \\
\hline 2 & Male & $\begin{array}{c}2.5 \text { months/ } 6 \\
\text { years }\end{array}$ & 12 & $\begin{array}{l}\text { Partial } \\
\text { thoracoabdominal }\end{array}$ & $\begin{array}{l}\text { DORV, VSD, } \\
\text { LPSVC, PS } \\
\text { (subpulmonic), } \\
\text { RV diverticulum }\end{array}$ & $\begin{array}{l}\text { Cleft palate } \\
\text { and lip }\end{array}$ & $\begin{array}{c}\text { Cleft palate and } \\
\text { lip repair mBT } \\
\text { shunt }\end{array}$ \\
\hline 4 & Female & Neonate & 5 & Mid sternal defect & ASD, PDA & & $\begin{array}{l}\text { Thoracic defect } \\
\text { repair and } \\
\text { ASD-PDA } \\
\text { closing }\end{array}$ \\
\hline
\end{tabular}

ASD: Atrial septal defect; AS: Aortic stenosis; LPSVC: Left persistent superior vena cava; DORV: Double outlet right ventricle; VSD: Ventricular septal defect; PS: Pulmonary stenosis; PDA: Patent ductus arteriosus; mBT: Modified Blalock-Taussig; RVD: Right ventricular diverticulum. 
maneuvers facilitated partial approximation of the sternum with steel wire sutures and closure of muscle, fascia, and skin layers (Figure 5b). The patient had an uneventful recovery with a normal development at her latest follow-up at the age of five years (Figure 5c). A written informed consent was obtained from each parent for all diagnostic and therapeutic procedures.

\section{DISCUSSION}

Ectopia cordis is a very rare congenital anomaly in which the heart or a part of it is located outside the body. It is frequently associated with Pentalogy of Cantrell which was first described in 1958. The etiology is uncertain. Some authors have proposed that the sternum and anterior chest wall defects are caused by abnormal development and migration of mesodermal cells in the third week of gestational development and the differentiation abnormality of these cells into somatic and splanchnic layers results in maldevelopment of the heart, pericardium, abdominal wall, and diaphragm. ${ }^{[2]}$

Prognosis is usually determined by the extent of the defect and the level of exposure of the heart. Additional cardiac defects are present in $80 \%$ of the cases and, also, determine the long-term prognosis. ${ }^{[4]}$ Our all four patients had some types of cardiac defect with two having ASDs and the other two having DORV with PS. In addition, one case had cleft palate/lip and the other two cases had omphalocele, which is the most common associated anomaly. Other common associated anomalies are cleft palate/lip, hydrocephalus, hypoplastic lung, diastasis recti, gastroschisis, and scoliosis. ${ }^{[5]}$ In severe forms, prenatal diagnosis can lead to a therapeutic abortion. ${ }^{[6]}$

Surgical repair of thoracic EC cases can be performed with difficulty and high mortality. In the presence of concomitant intracardiac anomalies, mortality may rise in parallel with the complexity of surgical intervention. The main goals of surgical treatment are as follows: covering the heart with a soft tissue; placing the heart in the thoracic cavity; if any, palliation or repair of the intracardiac defect; and reconstruction of the chest wall. ${ }^{[7]}$ When gradual surgery is adopted, the first attempt should be to cover the heart. In our first case, we aimed to protect the heart from external factors by covering the heart with a porcine pericardial patch and planned to carry out reconstruction of the chest wall in the future. In the next two cases, the exposed portion of the heart was covered with the natural tissue. The heart was protected adequately, and no additional procedure was necessary. In the final case, the heart was exposed, but the size of the defect allowed a complete primary closure with sternum, pectoralis major muscle, and skin mobilization. In the first case, primary cardiac problem was LVOT, as it entered into the mediastinum thru, a relatively small opening. The stenosis progressed, as the child grew and could not be corrected with surgery. In the two cases with DORV with significant PS, complete correction was unable to be performed due to anatomical considerations. Correction required placement of RV pulmonary artery conduit, which could not be positioned in the mediastinum. In the final patient, ASD was closed during the operation for EC.

In conclusion, ectopia cordis may present as a devastating malformation in the neonatal period. Based on our experience, exposure of the heart is the most important factor which determines the initial survival. If the heart and intraperitoneal structures are exposed, every effort should be made to cover these structures. If there is adequate tissue cover over the exposed organs, patients can be followed with routine dressing changes. Unfortunately, complex repairs of intracardiac defects could prove to be difficult in these cases, requiring shunts for long-term palliation.

\section{Declaration of conflicting interests}

The authors declared no conflicts of interest with respect to the authorship and/or publication of this article.

\section{Funding}

The authors received no financial support for the research and/or authorship of this article.

\section{REFERENCES}

1. Hornberger LK, Colan SD, Lock JE, Wessel DL, Mayer JE. Outcome of patients with ectopia cordis and significant intracardiac defects. Circulation 1996;94:32-7.

2. Cantrell JR, Haller JA, Ravitch MM. A syndrome of congenital defects involving the abdominal wall, sternum, diaphragm, pericardium, and heart. Surg Gynecol Obstet 1958;107:602-14.

3. Morales JM, Patel SG, Duff JA, Villareal RL, Simpson JW. Ectopia cordis and other midline defects. Ann Thorac Surg 2000;70:111-4.

4. Alphonso N, Venugopal PS, Deshpande R, Anderson D. Complete thoracic ectopia cordis. Eur J Cardiothorac Surg 2003;23:426-8.

5. Aydın S, Suzan D, Çevik M, Ödemiş E, Erek E. Pediatrik bir olguda tek ventriküllü kalp ve Cantrell sendromu. Turk Gogus Kalp Dama 2016;24:542-4.

6. Achiron R, Shimmel M, Farber B, Glaser J. Prenatal sonographic diagnosis and perinatal management of ectopia cordis. Ultrasound Obstet Gynecol 1991;1:431-4.

7. Aytac A, Saylam A. Successful surgical repair of congenital total cleft sternum with partial ectopia cordis. Thorax 1976;31:466-9. 